\title{
TAHAPAN KEMAMPUAN PENGEMBANGAN KOGNITIF BERBAHASA ANAK USIA DINI (4-5 TAHUN)
}

\author{
Sukrin \\ Institut Agama Islam (IAI) Muhammadiyah Bima \\ Email: mataharibiru69@gmail.com
}

\begin{abstract}
Abstrak:
Pengembangan dalam pertumbuhan kemampuan dasar pendidikan anak usia dini adalah pengembangan bahasa. Dalam hal ini, seorang anak usia dini berada dalam fase perkembangan bahasa ekspresif. Hal ini berarti bahwa anak telah dapat mengungkapkan keinginannya, penolaknnya, maupun pendapatnya dengan menggunakan bahasa lisan. Pemerolehan bahasa pada anak-anak memang merupakan salah satu prestasi manusia yang paling hebat dan sangat menakjubkan. Melalui bahasa, komunikasi antar anak dapat terjalin dengan baik sehingga anak dapat membangun hubungan.Tidak heran bahasa dianggap sebagai salah satu indikator kesuksesan seorang anak.Anak yang dianggap banyak berbicara, kadang merupakan cerminan anak yang cerdas. Dalam kemampuan berbahasa terdapat tiga lingkup perkembangan yaitu (1) Kemampuan berbahasa.Bahasa termasuk hal esensial di dalam perkembangan anak untuk mengoptimalkan potensi dan beradaptasi dengan dunia sekitar. (2) Kemampuan berbicara, pada tahap ini anak sudah mulai mampu berbicara secara teratur dan terstruktur. (3) Kemampuan mengungkapkan bahasa. Merupakan kemampuan yang dimiliki anak untuk mengungkapkan apa yang menjadi keinginannya. Kemampuan ini digunakan untuk menjalin komunikasi secara lisan dengan baik kepada orang lain.
\end{abstract}

Kata Kunci: Perkembangan, Kemampuan Bahasa, Anak Usia Dini.

\section{PENDAHULUAN}

$\mathrm{B}$

ahasa merupakan hal yang penting untuk berkomunikasi bagi setiap orang. Seorang anak akan mudah mengembangkan kemampuan bergaul (social skill) dengan orang lain melalui komunikasi yang dilakukannya. Penguasaan keterampilan bergaul dalam lingkungan sosial dimulai dengan penguasaan kemampuan berbahasa. Tanpa bahasa seseorang tidak akan dapat berkomunikasi dengan orang lain. Anak dapat mengekspresikan pikirannya menggunakan bahasa, sehingga orang lain dapat menangkap apa yang dipikirkan oleh anak. Melalui bahasa, komunikasi antar anak dapat terjalin dengan baik sehingga anak dapat membangun hubungan. Tidak heran bahasa dianggap sebagai salah satu indikator kesuksesan seorang anak.Anak yang dianggap banyak berbicara, kadang merupakan cerminan anak yang cerdas. Bahasa adalah alat penghubung atau 
merupakan komunikasi antar anggota masyarakat yang terdiri dari individu-individu yang menyatakan pikiran, perasaan dan keinginannya. Bahasa dapat dipelajari secara teratur tergantung pada kematangan serta kesempatan belajar yang dimiliki seseorang. Bahasa merupakan alat berkomunikasi dengan orang lain dan kemudian berlangsung dalam suatu interaksi sosial. Belajar bahasa yang sangat krusial terjadi pada anak sebelum usia enam tahun. Oleh karena itu, pendidikan anak usia dini merupakan wahana yang sangat penting dalam mengembangkan kemampuan berbahasa pada anak (Nurbiana, 2006). Dalam mengembangkan kemampuan tersebut hendaknya guru memperhatikan sifat-sifat kegiatan belajar PAUD yang berlangsung dengan cara-cara sederhana, kongkrit, dan kontekstual. Optimalisasi penguasaan kemampuan berbahasa ini tentunya akan sangat didukung dengan metode pembelajaran yang tepat sehingga apa yang diinginkan akan berkembang sesuai dengan perkembangan anak.

\section{Tahapan Dalam Meningkatkan Kemampuan Berbahasa Anak Usia Dini}

Salah satu bidang pengembangan dalam pertumbuhan kemampuan dasar pendidikan anak usia dini adalah pengembangan bahasa. Dalam Depdiknas, dijelaskan bahwa kemampuan berbahasa merupakan salah satu dari bidang pengembangan kemampuan dasar yang disiapkan oleh guru untuk meningkatkan kemampuan dan kreativitas anak sesuai dengan tahap perkembangannya. Bahasa merupakan landasan bagi seorang anak untuk mempelajari hal-hal lain. Sebelum dia belajar pengetahuan-pengetahuan lain, dia perlu menggunakan bahasa agar dapat memahami dengan baik. Anak akan dapat mengembangkan kemampuannya dalam bidang pengucapan bunyi, menulis, membaca yang sangat mendukung kemampuan keaksaraan di tingkat yang lebih tinggi. Pada aspek pengembangan bahasa, kompetensi dan hasil yang diharapkan adalah anak mampu menggunakan bahasa sebagai pemahaman bahasa pasif dan dapat berkomunikasi secara efektif yang bermanfaat untuk berfikir dan belajar dengan baik.

Anak usia dini berada dalam fase perkembangan bahasa ekspresif. Hal ini berarti bahwa anak telah dapat mengungkapkan keinginannya, penolaknnya, maupun pendapatnya dengan menggunakan bahasa lisan. Pemerolehan bahasa pada anak-anak memang merupakan salah satu prestasi manusia yang paling hebat dan sangat menakjubkan, dimana kita bisa mengetahui bagaiamana anak-anak berbicara, mengerti dan menggunakan bahasa tetapi sangat sedikit sekali yang kita ketahui adalah bahwa pemerolehan bahasa sangat banyak ditentukan oleh interaksi rumit 
aspek-aspek kematangan biologis, kognitif dan sosial. Menurut Martinis (2004), menjelaskan bahwa pada tahap ini bahasa lisan sudah dapat digunakan anak sebagai alat komunikasi. Ada beberapa aspek yang berkaitan dengan perkembangan bahasa pada anak yang meliputi penggunaan kosa kata, sintak (tata bahasa), semantik (penggunaan kata sesuai tujuannya) dan fonem (bunyi kata). Berbahasa mencakup 4 aspek terpisah tetapi saling berhubungan satu sama lain. Karena saling berkaitan, kegagalan menguasai salah satunya akan membahayakan keseluruhan pola berbahasa anak. Berdasarkan pendapat para tokoh maka dapat disimpulkan bahwa kemampuan berbahasa anak usia dini yaitu bahasa lisan yang digunakan seseorang untuk menyampaikannya, mengekspresikan, meyatakan atau mengkomunikasikan keinginan, pikiran, pendapat, penolakan kepada orang lain dengan tujuan lawan bicara dapat mengerti maksud yang disampaikan. Pengembangan bahasa diarahkan agar anak mampu menggunakan dan mengekspresikan pemikirannya dengan menggunakan kata-kata.

\section{Tahap Kemampuan Berbahasa}

Kemampuan bahasa anak tidak saja dipengaruhi oleh perkembangan neurologis tetapi juga oleh perkembangan biologisnya.Ada keterkaitan antara perkembangan biologi dengan kemampuan berbahasa. Beberapa tahap dalam bahasa ekspresif anak yaitu: ketika bayi, ia "bicara" dalam bahasa tangis. Pada usia 6 minggu 3 bulan, bayi mulai mengembangkan sistem komunikasinya menjadi cooing (ocehan tanpa arti yang jelas). Babbling, atau keluarnya suara mirip suku kata, tampak pada usia 6-10 bulan. Memasuki usia 1 tahun, anak telah dapat mengucapkan kata pertamanya. Tidak lama setelah itu, mereka mulai menggabungkan dua kata untuk berbicara.anak usia 2 tahun telah dapat melakukan komunikasi dengan kalimat sederhana.Di usianya yang ketiga anak telah mampu menceritakan tentang kejadian pada saat itu. Anak usia 4-6 tahun telah berbicara dan berbahasa seperti layaknya orang dewasa.

Pemerolehan bahasa anak dapat dikatakan mempunyai ciri dan khas kesinambungan, memiliki suatu rangkaian kesatuan yang bergerak dari ucapan satu kata sederhana menuju gabungan kata lebih rumit.Dengan demikian, bahasa termasuk hal esensial di dalam perkembangan anak utntuk mengoptimalkan potensi dan beradaptasi dengan dunia sekitar. Ada 3 tahap perkembangan bahasa anak yang menentukan tingkat perkembangan berfikir, yaitu tahap eksternal, egosentris dan internal. Tahap ekternal yaitu tahap berfikir anak berasal dari luar dirinya, sumber 
eksternal tersebut terutama berasal dari orang dewasa yang memberi pengarahan kepada anak dengan cara tertentu. Tahap egisentris merupakan suatu tahap ketika pembicaraan orang dewasa tidak lagi persyaratan, dengan suara khas, anak berbicara seperti jalan pikirannya. Selanjutnya tahap internal adalah suatu tahap ketika anak menjadi menghayati proses berfikir (Martinis, 2004).

Menurut Steinberg dan Gleason dalam Suhartono, bahwa perkembangan bicara atau bahasa ekspresif anak dibagi menjadi tiga tahap, yaitu : perkembangan pra sekolah, perkembangan kombinatori, dan perkembangan masa sekolah. Selain hal tersebut, terdapat beberapa tahapan dalam perkembnagan bahasa Anakk anatara sebagai berikut:

a. Tahap penanaman, anak baru mulai mampu mengujarkan urutan bunyi kata tertentu dan ia belum mampu memaknainya. Urutan bunyi yang diucapakannya biasanya terbatas dalam satu kata.

b. Tahap telegrafis, anak sudah mulai dapat menyampaikan peran yang diinginkannya dalam bentuk urutan bayi yang berwujud dua atau tiga kata untuk mengganti kalimat yang berisi maksud tertentu da nada hubungannya dengan makna.

c. Tahap transformasial, anak mulai berani mentransformasikan idenya kepada orang lain dalam bentuk kalimat yang beragam.

\section{Tahap Perkembangan Berbicara}

a. Perkembangan bicara kombinatori, pada tahap ini anak sudah mulai mampu berbicara secara teratur dan terstruktur. Bicara anak dapat dipahami oleh orang lain dan anak sanggup merespon dengan baik positif maupun negatif atas pembicaraan lawan bicaranya.

b. Perkembangan bicara masa sekolah, merupakan perkembangan bicara anak sejak memasuki sekolah dasar. Perkembangan bicara ini sudah dapat dibedakan menjadi tiga bidang, yakni struktur bahasa, pemakaian bahasa dan kesadaran metalinguistik (Suhartono, 2005).

Dengan melihat beberapa tahap perkembangan tersebut, maka anak harus selalu mendapatkan stimulus sesuai dengan tahap perkembangannya, agar kemampuan berbahasa anak dapat memenuhi target yang sesuai dengan usia perkembangannya. Guru juga harus memberikan stimulus berupa pembelajaran yang sesuai dengan tahapan perkembangan anak. Bahasa dapat berkembang cepat jika anak memiliki kemampuan dan didukung oleh lingkungan yang baik. 
Kemampuan berbahasa dapat berkembang dengan baik apabila ada faktor yang mendukungnya. Ada beberapa faktor yang dapat mempengaruhi kemampuan bahasa yaitu :

a. Anak berada di dalam lingkungan yang positif dan bebas dari tekanan. Lingkungan yang positif akan menstimulasi perkembangan bahasa anak. Stimulasi tersebut akan optimal jika anak tidak merasa tertekan, anak yang mengalami tekanan dapat menghambat kemampuan berbicaranya.

b. Menunjukkan sikap sikap dan minat yang tulus pada anak. Anak usia dini emosinya masih kuat karena itu guru harus menunjukkan minat dan perhatian tinggi kepada anak. Prang dewasa perlu memberikan respon kepada anak yang tulus.

c. Menyampaikan pesan verbal diikuti dengan pesan nonverbal.

d. Dalam bercakap-cakap dengan anak, orang dewasa perlu menunjukkan ekspresi yang sesuai dengan ucapannya. Perlu diikuti dengan gerakan, mimik muka dan intonasi yang sesuai sehingga anak dapat mengetahui dengan jelas apa yang dimaksudkan.

e. Melibatkan anak dalam berkomunikasi. Orang dewasa perlu melibatkan anak untuk ikut membangun komunikasi. Kita menghargai ide-idenya dan memberikan respon yang baik terhadap bahasa anak (Yasmin, 2003).

Berdasarkan hal tersebut maka dapat disimpulkan bahwa dalam kemampuan berbahasa anak usia dini, ada beberapa faktor yang mempengaruhinya. Lingkungan sekitar anak sangat menentukan dalam keberhasilan anak, selain itu komunikasi yang dilakukan anak dengan orang dewasa akan menstimulasi kemampuan berbahasa anak usia dini.

\section{Tahap Kemampuan Mengungkapkan Bahasa}

Kemampuan berbahasa untuk anak usia dini berdasarkan acuan standar pendidikan anak usia dini yang tercantum pada peraturan Menteri Pendidikan Nasional No.58 Tahun 2009, terdapat tiga lingkup perkembangan yaitu menerima bahasa represif, mengungkapkan bahasa ekspresif dan keaksaraan. Anak usia dini berada dalam fase bahasa ekspresif. Hal ini sesuai dengan pendapatan Moeslichatoen, bahwa bahasa ekspresif adalah kemampuan yang dimiliki anak untuk mengungkapkan apa yang menjadi keinginannya. Anak-anak dapat berbicara sesuai dengan aturan-aturan tata bahasa, dapat memahami kosa kata yang didengarkan dalam percakapan yang umum dikenal.Anak-anak belajar berbahasa, sebagaimana 
mereka memperoleh pengetahuan lainnya, yakni melalui pengalaman (Moeslichatoen $R$, 2004). Sejalan dengan pendapat tersebut maka kemampuan mengungkapkan bahasa termasuk kedalam bahasa ekspresif.Pada kemampuan mengungkapkan bahasa ada beberapa tingkat pencapaian perkembangan yang harus dicapai oleh anak yang meliputi mengulang kalimat sederhana, menjawab pertanyaan sederhana, mengungkapkan perasaan dengan kata sifat, menyebutkan kata-kata yang dikenal, mengutarakan pendapat kepada orang lain, memyatakan alasan terhadap sesuatu yang diinginkan atau ketidak setujuan dan menceritkan kembali sesuatu yang diperdengarkan.Standar inilah yang dijadikan tolak ukur keberhasilan anak terhadap kemampuan mengungkapkan bahasa. Dikarenakan keterbatasan waktu dan beberapa faktor lainnya maka dari beberapa tingkat pencapaian perkembangan tersebut penelitian ini memfokuskan pada aspek mengulang kalimat sederhana, menjawab pertanyaan sederhana, dan mengutarakan pendapat kepada orang lain.

Dengan demikian kemampuan mengungkapkan bahasa sangat berperan penting dalam menyiapkan anak untuk dapat berkomunikasi dengan baik kepada orang disekitarnya maka perlu adanya stimulus yang diberikan agar dapat berkembang secara optimal sesuai tahapan usia anak. Pada kemampuan mengungkapkan bahasa terdapat beberapa hal yang dapat dijadikan landasan dalam mengukur sejauh mana kemampuan yang anak miliki.

\section{Karakteristik Dan Prinsip Pengembangan Bahasa Anak Usia Dini 4-5 Tahun}

\section{Karakteristik Pengembangan Bahasa Anak Usia Dini}

Pada bahasa ekspresif terdapat beberapa karakteristik yang harus diketahui sehingga mampu menstimulus kemampuan bahasa ekspresif secara optimal. Menurut Jumaris Martini dalam Fatimatus perkembangan bahasa anak usia 4-5 tahun adalah:

a. Sudah dapat mengucapkan lebih dari 2500 kosa kata (menyangkut warna, ukuran, bentuk, rasa, bau, keindahan, kecepatan, suhu, perbedaan, perbandingan, jarak, dan permukaan).

b. Sudah dapat berpartisipasi dengan suatu percakapan.

c. Dapat mendengarkan orang lain berbicara dan menanggapi pembicaraan tersebut.

d. Percakapan yang dilakukan telah menyangkut komentarnya yang dilakukan oleh dirinya sendiri dan orang lain serta apa yang dilihatnya (Yasmin, 2003). 
Dalam pandangan literatura lain juga disebutkan bahwa Perkembangan bahasa anak usia 4-5 tahun mencakup tahapan sebagai berikut :

a. Berbicara lancar dengan kalimat sederhana

b. Menyebutkan sebanyak-banyaknya nama benda, binatang, atau menurut ciriciri tertentu.

c. Berbicara tentang kejadian di sekitarnya secara sederhana.

d. Mengurutkan dan menceritakan si gambar seri (2-3 gambar).

e. Bercerita tentang gambar yang di buat sendiri.

f. Mengikuti 1-2 perintah sekaligus.

g. Membuat sebanyak-banyaknya kata dari suku kata awal yang di sediakan dalam bentuk lisan seperti : mama, malu, marah dan sebagainya (Rosmala Dewi, 2005).

Menurut Permen No. 137 Tahun 2014, indikator capaian perkembangan bahasa dalam aspek mengungkapkan bahasa anak usia 4-5 tahun adalah sebagai berikut :

a. Mengulang kalimat sederhana.

b. Bertanya dengan kalimat yang benar.

c. Menjawab pertanyaan sesuai dengan pertanyaan.

d. Mengungkapkan perasaan dengan kata sifat (baik, senang, nakal, pelit, baik hati, berani, jelek, dsb).

e. Menyebutkan kata-kata yang dikenal.

f. Mengutarakan pendapat kepada orang lain.

g. Menyatakan alasan terhadap sesuatu yang diinginkan atau ketidak setujuan.

h. Menceritakan kembali cerita/dongeng yang pernah didengar.

i. Memperkaya perbendaharaan kata.

j. Berpartisipasi dlam percakapan (Depdiknas, 2014).

Karakteristik dalam kemampuan bahasa ekspresif dapat dijadikan landasan untuk mengukur sejauh mana perkembangan yang telah dicapai oleh anak.Sehingga tujuan dari pembelajaran dapat menstimulus kemampuan bahasa ekspresif yang anak miliki secara optimal.Karaktersitik dari bahasa ekspresif inilah yang dapat dijadikan sebagai landasan dari kemampuan mengungkapkan bahasa. Dengan kata lainkarakteristik kemampuan mengungkapkan bahasa yaitu kemampuan yang memiliki tahap-tahap tersendiri yang salinf berkesinambungan antara satu dengan yang lainnya sehingga pengembangan bahasanya sesuai dengan tahapan usia anak. 
Tahapan tersebut dijadikan landasan dalam upaya menstimulus kemampuan mengungkapkan bahasa.Sehingga stimulus yang diberikan tidak terlepas dari tujuan pembelajaran.

\section{Prinsip Pengembangan Bahasa Anak Usia Dini}

Ada beberapa prinsip kemampuan berbahasa yang dapat dijadikan landasan dalam pengembangan kemampuan mengungkapkan bahasa sebagaimana yang disajikan oleh Depdiknas, sebagai berikut :

a. Sesuai dengan tema kegiatan dsn lingkungan terdekat.

b. Pembeljaran harus berorientasi pada kemampuan yang hendak dicapai sesuai dengan potensi anak.

c. Tumbuh kebebasan dalam mengungkapkan pikiran dan perasaan dikaitkan dengan spontanitas.

d. Diberikan alternatif pikiran dalam mengungkapkan isi hatinya.

e. Komunikasi guru dan anak akrab dan menyenangkan.

f. Guru menguasai pengembangan bahasa.

g. Guru bersikap normatif, model, contoh penggunan bahasa yang baik dan benar.

h. Bahan pembelajaran membantu pengembangan kemampuan dasar anak.

i. Tidak menggunakan huruf satu-satu secara formal (Depdiknas, 2001).

Terdapat kaitan antara kognitif dengan bahasa.Pada awalnya pikiran dan bahasa berkembang secara terpisah dan tidak saling mempengaruhi.Jadi mulamula pikiran berkembang tanpa bahasa dan bahasa mula-mula berkembang tanpa pikiran, lalu pada tahap berikutnya keduanya saling bertemu dan bekerjasama serta saling mempengaruhi. Menurut Vygotsky dalam Santrock pikiran dan berbahasa berkembang melalui beberapa tahap.Mula-mula anak mengucapkan kata untuk dipahami. Kemudian bergerak ke arah untuk dimengerti.Langkah selanjutnya adalah mampu memisahkan kata-kata yang berarti dan tidak berarti (Santrock, 2002). Prinsip zone of proximalyaitu zona berkaitan dengan perubahan dari potensi yang dimiliki oleh anak menjadi kemampuan aktual maka prinsipprinsip pengembangan bahasa anak berupa interaksi anak dengan lingkungan sekitarnya dapat membantu anak memperluas kosa katanya dan memperoleh contoh-contoh dalam menggunakan kosa kata tersebut secara tepat, selanjutnya mengekspresikan kemampuan berbahasa.Ekspresi kemampuan pada anak untuk mengungkapkan pikiran dan perasaannya secara tepat (Martinis, 2003). 


\section{SIMPULAN}

Dari urutan yang telah dijelaskan sebelumnya, dapat disimpulkan bahwa kemampuan berbahasa adalah bahasa lisan yang digunakan untuk menyampaikan keinginan, pendapat, gagasan, ide, maupun penolakan kepada orang lain sehingga apa yang disampaikan dapat dipahami oleh lawan bicara. Dalam kemampuan berbahasa terdapat tiga lingkup perkembangan yaitu (1) Kemampuan berbahasa.Bahasa termasuk hal esensial di dalam perkembangan anak untuk mengoptimalkan potensi dan beradaptasi dengan dunia sekitar. (2)kemampuan berbicara, pada tahap ini anak sudah mulai mampu berbicara secara teratur dan terstruktur. (3) kemampuan mengungkapkan bahasa. Merupakan kemampuan yang dimiliki anak untuk mengungkapkan apa yang menjadi keinginannya. Kemampuan ini digunakan untuk menjalin komunikasi secara lisan dengan baik kepada orang lain.

\section{DAFTAR PUSTAKA}

Departemen Pendidikan dan Kebudayaan. 1990. Kamus Besar Bahasa Indonesia, Jakarta: Balai Pustaka.

Henry Guntur Tarigan. 1993. Berbicara Sebagai Sesuatu Keterampilan Berbahasa, Bandung: Angkasa.

Jamaris, Martinis. 2004. Perkembangan Dan Pengembangan Anak Usia Taman Kanak-Kanak, Jakarta: Universitas Negeri Jakarta.

Moeslichatoen R. 2004. Metode Pembelajaran Di Taman Kanak-Kanak, Jakarta: Rineke Cipta.

Nurbiana Dkk. 2006. Metode Pengembangan Bahasa, Jakarta: Universitas Terbuka.

Suhartono. 2005. Pengembangan Keterampilan Bicara Anak Usia Dini, Jakarta: Departemen Pendidikan Nasional.

Yedi Kurniawan. 1993. Pendidikan Anak Sejak Dini Hingga Masa Depan :Tinjauan Islam dan Permasalahannya, Jakarta: Firdaus. 